\title{
CAUSE-RELATED MARKETING UNDER THE LENS OF FUNDRAISING METHODS
}

\author{
Andreea-Angela ȘEULEAN (VONȚEA) \\ Bucharest University of Economic Studies, Bucharest, Romania \\ andreea.vontea@mk.ase.ro
}

\begin{abstract}
The nonprofit sector and the organizations that define it are characterized by a particular approach. In this regard, NGOs' overall activity is strongly influenced by their ability of financing it through a generous palette of fundraising methods. The current paper is centered on one of the most used ones, namely the one of cause-related marketing. In this regard, it could be assumed that it acts as a connecting element between the represented social cause and the financial support that could be obtained through financial means from a corporate entity that decides to integrate its own brand image. Moreover, given the fact that it is transaction-based, the fundraising method under discussion requires the presence of a third-party, namely the one of the consumer that decides to support the social cause represented by the nonprofit organization that involves itself in such a mutually beneficial program.
\end{abstract}

Keywords: Cause-related marketing, Fundraising, NGO, Donor, Corporate social responsibility

\section{INTRODUCTION}

The current coordinates of the nonprofit sector reveal the importance of marketing activities and, at the same time, the need for information designed to describe the field in terms in which it manifests itself. The dynamism of the marketing environment in which NGOs operate requires a proactive reference, translated by a potential redesign, both from a strategic and a conceptual point of view of the biunique relationships that describe the interaction with the market's components (Hou, Du \& Tian, 2009; Brady et al., 2011).

Amid the growing importance of the philanthropy, we assist at the proliferation of the social activities of the organizations oriented towards obtaining profit. The philanthropic activities represent, in essence, a strategic matter, impossible to be separated from the overall strategy of the company. The company's social responsibility can be considered a key-asset as its operationalization supports the legitimacy of the business practices in relation with the society, generally, as well as with the stakeholders, specifically. Furthermore, in order to achieve the marketing objectives, the motivations of the companies' endeavors of social involvement converge towards selecting causes that can create value 
(Ingenbleek, Binnekamp \& Goddijn, 2007; Merz, Peloza \& Chen, 2010; Liu \& Ko, 2011; Stancu, 2012). From the perspective of promoting the social responsibility initiatives, cause-related marketing (CRM) can be considered an effective tool. In addition, its emergence represented a defining frame for aligning, from strategic considerations, both corporate and philanthropic objectives, at the level of all the facets of the company's promotional strategy (Liu \& Ko, 2011; Thomas, Mullen \& Fraedrich, 2011).

Considered in its whole, the NGO's activity is strongly influenced by its financial resources. Since the social causes, for which the NGOs are concerned, can be considered a precedent of the companies' decision of involving themselves in cause-related marketing programs, it is necessary to take into account the inter-conditioning between the corporate charitable donation's value and the purchases made by consumers regarding an established product (Wymer \& Samu, 2009). In this manner, the financing does not come only from one source - the company as a corporate donor -, but it also includes the indirect contribution of the consumer to whom a new role is assigned, namely that of individual donor.

This paper integrates three parts. In the first part, the concept of cause-related marketing is presented with reference to the company's social responsibility, after which the second one describes a series of peculiarities. The third part aims to reveal the benefits of the NGOs involved in such programs, from the perspective of the funds they have, resulted from the joining of the direct contribution, respectively of the indirect one, of two categories of donors - the company and the consumer.

\section{CAUSE-RELATED MARKETING REGARDED AS A VALUABLE INITIATIVE OF CORPORATE SOCIAL RESPONSIBILITY}

In a broad sense, in a lucrative organization four elements of major importance can be found: (1) the core ideology, (2) the products and the services, (3) the business processes, and (4) the societal commitment directions, each of them requiring a different instrumental approach. In a narrow sense, from the perspective of approaching the social involvement in an integrated manner, an interdependent relationship exists between them, the implications of which influence the company, both in terms of opportunities and threats (Crittenden et al., 2011).

The long term profitability, the risk management, and the achievement of a competitive advantage are some of the most frequent references, in relation with the company's motivations regarding the decision of acting in a socially responsible manner (Kolk \& van Tulder, 2010; Sheikh \& Beise-Zee, 2011). Sprinkle \& Maines (2010) refer to the social involvement of the company from a different perspective, namely its equivalence with another cost of operating in the business environment. This last iteration 
can be considered contrary to the trends of the current conduct of the companies, given the development of the corporate social responsibility concept (CSR), on the basis of switching from the social involvement as obligation, to the social involvement as strategy (Stancu, 2012).

In order to acquire an efficient communication, the focus on some social issues is often desirable, this endeavor being able to improve the receptivity of a given company's target audience. Hence, the financial or nonfinancial support given to a certain cause is a generic vehicle to communicate the effort regarding the CSR activities, the cause being an identifier in this respect (Sheikh\& Beise-Zee, 2011).

Among the social responsibility initiatives, a distinctive place is occupied by the manner in which a company reports itself to the social issues that it can address. Thereby, Kotler \& Lee (2005 cited in Stancu, 2012) place cause-related marketing among the strategies of the companies' involvement in society. Because, conceptually, cause-related marketing represents the equivalent of the cause's specificity regarding the corporate social responsibility, it is important to clarify the fact that between CRM and CSR there is a part-whole report (Sheikh\& Beise-Zee, 2011).

\section{THE PARTICULAR ASPECTS THAT DEFINE THE CONCEPT OF CAUSE-RELATED MARKETING}

The cause-related marketing concept has been defined for the first time in 1988 by Varadarajan and Menon as being 'the process of formulating and implementing the marketing activities characterized by an offer from a company in order to contribute to a designated cause when the clients make purchases'. According to other authors, into such programs 'the emphasis is put on the transaction from which the corporate entities contribute with a certain amount to supporting a designated cause, when consumers purchase their products' (Cornwell \& Coote, 2005, p. 268).

In conceiving the conceptual delimitation of CRM, we consider that its place in the field of corporate societal marketing is relevant - 'marketing efforts which integrate at least one economic objective related to social welfare and use the company's resources and/ or of its partners' (Drumwright \& Murphy, 2001 cited in Kotler et al., 2009, p. 792). In relation with the taxonomy of the CRM implementation strategies, Liu \& Ko (2011, pp. 255-256) suggest a range of four options: a) sponsorship, b) transaction-based, c) joint promotion, and d) in-kind contribution. As the definitions refer to the concept of exchange materialized as transaction, we can infer that the latter represents the central element of approaching CRM. Furthermore, as opposed to sponsorship, the first element which occurs in the case of CRM is represented by the consumer behavior and then, as a result, the company makes a donation in order to support the cause (Cornwell \& Coote, 2005). Given the previous definitions and statements, we agree on the idea that the key-element of cause-related marketing 
reveals the fact that the donation offer is conditioned by the consumer, committing himself in a revenue producing transaction with a partner (oriented towards obtaining profit) of the NGO (Thomas, Mullen \& Fraedrich, 2011). Consequently, in a CRM context, we refer to three categories of entities - company, nonprofit organization (as a certain cause representative), and consumer.

According to Gipp, Kalafatis \& Ledden (2008), four motivational orienting directions are associated with the company's decision of supporting an NGO and, thus, with the cause for which it advocates maximizing the profit in a strategic manner, the altruistic motivation, the political motivation, and the managerial utility motivation. In consequence, due to the integrated marketing instruments, CRM influences the company's organizational identity in terms of forming and reformulation (Moosmayer \& Fuljahn, 2010; Liu \& Ko, 2011). More than that, a potential image transfer from the NGO to the company can improve the assessment made by the consumer towards the corporate behavior.

As in the case of the decision of purchasing a certain commercial product, the decision taken by consumers regarding the donation towards the NGO which should be chosen, will be influenced by its organizational brand because it is able to confer uniqueness, fact that will allow the consumers to distinguish between the brand of a certain NGO from that of competitors (Hou, Du \& Tian, 2009). Several studies indicate that the reputation is the most important intangible asset hold by NGOs, situation that determines their representatives to be more and more aware of the importance of the marketing concepts as organizational identity, or brand image and personality. The organizational identity also reflects itself into the cause related to the NGOs' object of activity, so that the corporate donor is influenced in terms of brands included in its portfolio or identity (Sarstedt \& Schloderer, 2010; Thomas, Mullen \& Fraedrich, 2011). So, the image attached to the social cause is projected over the company which involves itself in supporting it.

The results of research concerning the manner in which the congruence influences the attitudes towards the companies involved in CRM programs, highlighted that the effect of congruence is a very strong one. It can be a compensatory factor when negative attitudes are expressed towards the company, and transferred to the NGO (Thomas, Mullen \& Fraedrich, 2011). Thus, the congruence between the profile of a company and a charitable cause influences the success probability of the activities included in the field of cause-related marketing, but it is not advisable to absolutize this issue, as situations in which there is no direct relation between the two elements have been revealed. Although, in general, it is considered that all the entities involved in a CRM program obtain benefits, there are problematic situations, as well (Sorribas, 2007; Sheikh \& Beise-Zee, 2011). Consumers can condemn the company's involvement in CRM programs when they perceive the initiative as being one 
which exploits the social cause, in the sense in which its economic interest prevails or is wanted to convey an inaccurate image.

\section{BENEFITS ASSOCIATED WITH NGOS' INVOLVEMENT IN CAUSE-RELATED MARKETING PROGRAMS}

An important reference in approaching the nonprofit sector resides in knowing the differences between the organizations activating in it, and those which operate in the commercial sector. In this respect, Laidler-Kylander \& Simonin (2009) indicate five orienting directions - the organizational culture, the human resources, the collaborative approaches, the clients' complexity and the mission's importance. In addition, it is relevant to mention the fact that, in the nonprofit sector, it is necessary to distinguish, by using a rigorous terminological distinction, between the customers and the users of the products or services. So, the customers are part of the donors' component (individual and/ or institutional), while the users are, practically, the beneficiaries or the target group. This reveals the fact that the social activities' market integrates two components with which the NGO has exchange relationships, a subordination report existing between them (Zaharia, 2001).

The interaction with the donors, having as default end the fundraising activity, represents only the means by which the social objectives can be achieved. On applying the marketing principles, the expectations in terms of objectives differ in the case of target groups, than in that of donors (Brady et al., 2011). Thus, an increased awareness is aimed in order to multiply the possibilities of influencing the behavior, respectively, improving the performance with regard to the fundraising activity.

Given that in the social activities' market, the relationship between the nonprofit organization and its donors has a defining influence on the financial resources that it has, it is necessary to take into account the fact that the whole activity of the nonprofit organization depends on the manner in which they are managed. In this regard, Hedrick (2009, pp. 220-221) exhibits five trends:

- Donor-centered approach - the donors represent the core element of the fundraising activities;

- Donors' behaviors - the differentiations between the categories of donors are based on a series of segmentation criteria;

- Donors' relations' status - the interaction with the donors is approached in a professional manner;

- Websites - the coordinates of the relationships with the donors are communicated by the integrated informational content; 
- Outcomes and impact - the reporting includes both quantitative and qualitative information, describing the finalities of the support of which the NGO benefits.

The literature (Sargeant, 1999; Kotler \& Lee, 2008) renders different points of view on classifying the categories of donors, the NGOs' financing arriving from three - individual donors, corporate donors, and trusts/ foundations -, or from five sources - governmental grants and credits, foundations, media partners, coalitions and other partnerships, and corporations. On the basis of the variation of the costbenefit indicators characterizing the potential financial sources of financing the NGOs' activity, their segmentation on categories becomes a premise of the continuity, but a reference to some strategic considerations is also necessary (Ashley \& Faulk, 2010).

In relation with the categories of donors that are considered of priority on the basis of the objective of the paper, the individual ones will have as guiding element the public reporting, activities integrating an assessing role, and audited financial situations. A series of information is added to these components referring to the effectiveness in allocating the resources through programs, as well as the financial sustainability, information having, in their turn, the capacity to influence the quantum of the funds that the NGOs can obtain from companies (Zainon et al., 2011).

When a nonprofit organization opts for getting involved in a CRM program, we can state that it becomes the company's partner in the endeavor of supporting the social cause, situation favorable to increase the financial resources, or to achieve a degree of differentiation in relation with the potential competitors. Moreover, the NGO will benefit of an increased awareness, of an improved attitude, but also of a higher level of involvement, translated by the foundation of the support intention. Nevertheless, besides the associated advantages, aspects as losing the organizational flexibility, the high dependence on the financing obtained from the business environment, and the partnership with a company of which conduct is not an ethical one, are as many possible risks related to the role assumed by the NGO in a CRM program (Laidler-Kylander \& Simonin, 2009; Bigné-Alcañiz et al., 2010; Thomas, Mullen \& Fraedrich, 2011). Such situations can be prevented on the basis of a thorough monitoring of all the implications associated to a partnership relation. It is also important that when negative references are identified, corrective measures are applied. In order to optimize the manner in which the funds that the NGOs have are managed, Weerawardena, McDonald \& Mort (2010) indicate four strategic options revenues generated on commercial basis, applying commercial principles in the field of fundraising, using relationship marketing, and signing inter- and intra-sectorial strategic alliances.

As we mentioned previously, the third entity from a CRM program, besides the company and the NGO, is the consumer. The association between the brand included in the company's portfolio and the cause supported by the NGO, provides an auxiliary benefit to the consumer - in addition to the benefit related 
to the brand, he also obtains an additional benefit, related to the support of a cause. Accordingly, it could be concluded that, besides the fact that by operationalizing CRM, the NGO raises funds, and the exposure of the social cause raises, we can also discuss about the opportunity given to the consumers, that of being involved in improving the quality of life (Wymer \& Samu, 2009; Kotler et al., 2009). If initially, in relation with the corporate entity, the individual has the status of consumer, afterwards, from the NGOs' perspective, we can affirm that he acquires a new role, namely that of donor. In consequence, as the financing coming from the corporate donor is determined by that from the individual donor, we can conclude that the operationalization of cause-related marketing is founded, practically, by a derived financing. At a first analysis of the manner of practical approaching CRM, we could be determined to consider that the only entity of whom contribution makes sense from the optic of the NGOs' financial resources, is represented by the company itself, when is part of the program. According to the purpose of the article, we reiterate the fact that by operationalizing a CRM program, to the NGO and, implicitly, to the charitable cause of which it is concerned, are associated funds coming from two different sources - on one side, the company and, on another side, the individual. Even if the financial support which is characteristic to it, it is not achieved directly, it is important to be taken into account. On the basis of this approach, the involvement in a CRM program, from the perspective 0 the funds of the NGO, becomes entirely justified.

\section{CONCLUSIONS}

Cause-related marketing, as a corporate social responsibility initiative, represents a tool that is available to companies that choose to support a given social cause, integrating, as a central element, a transaction. In this respect, the value of the corporate financial contribution is determined by the purchases made by the consumer of the product associated to the cause.

Generally, a nonprofit organization is responsible for the social cause representing the object of a CRM program. Hence, besides the company and the consumer, we take into account a third entity. In correspondence with the latter, the dimension to which the positive finalities of participating in a CRM program were outlined is related to fundraising. Consequently, the paper aimed to emphasize the fact that the involvement in CRM programs has a unique characteristic, namely the fact that the NGO benefits both from a direct financial contribution (from the part of the company), and from an indirect one (from the part of the consumer), situation which postulates a new role to the consumer - that of individual donor.

Therefore, the social involvement of the company, materialized by the commitment in a CRM program, does not integrate a unilateral approach because, on the base of conditioning the financial support by 
the purchases made by the consumers, it engages another entity as well, registered, in its turn, among the potential sources of provenance of the funds of the NGO, being featured by a conjugated effort.

By its purpose, the paper offers an overall perspective on the cause-related marketing concept, highlighting the importance of orientating the mutual effort of the company and of the consumer in order to support, from a financial point of view, the charitable cause for which the NGO is responsible. Due to the fact that the marketing communications have a defining role in the terms of the interaction between the NGO and the components of its activities' market, the permanent reference to the represented social cause's attributes, can be a real source of competitive advantage, given the coordinates of the nonprofit sector.

\section{REFERENCES}

Anghel, L.D., Grigore, G.F. \& Roşca, M. (2011). Cause-related marketing, part of corporate social responsibility and its influence upon consumers' attitude. Amfiteatru Economic. XIII(29): 72-85.

Ashley, S. \& Faulk, L. (2010). Nonprofit competition in the Grants Marketplace - Exploring the Relationship Between Nonprofit Financial Ratios and Grant Amount. Nonprofit Managenent \& Leadership. 21(1): 43-57.

Bigné-Alcañiz, E., Currás-Pérez, R., Ruiz-Mafé, C. \& Sanz-Blas, S. (2010). Consumer behavioural intentions in cause-related marketing. The role of identification and social cause involvement. International Review on Public and Non Profit Marketing. 7(2): 127-143.

Brady, E., Brace-Govan, J., Brennan, L. \& Conduit, J. (2011). Market orientation and marketing in nonprofit organizations. Indications for fundarising from Victoria. International Journal of Nonprofit and Voluntary Sector Marketing. 16(1): 84-98.

Cornwell, T.B. \& Coote, L.V. (2005). Corporate sponsorship of a cause: the role of identification in purchase intent. Journal of Business Research. 58(3): 268-276.

Crittenden, V.L., Crittenden, W.F., Pinney, C.C. \& Pitt, L.F. (2011). Implementing global corporate citizenship: An integrated business framework. Business Horizons. 54(5): 447-455.

Gipp, N., Kalafatis, S.P. \& Ledden, L. (2008). Perceived value of corporate donations: an empirical investigation. International Journal of Nonprofit and Voluntary Sector Marketing. 13(4): 327-346.

Hedrick, J.L. (2009). Effective donor relations. Hoboken, NJ: John Wiley \& Sons.

Hou, J., Du, L. \& Tian, Z. (2009). The effects of nonprofit brand equity on individual giving intention: mediating by the self-concept of individual donor. International Journal of Nonprofit and Voluntary Sector Marketing. 14(3): 215-229.

Ingenbleek, P., Binnekamp, M. \& Goddijn, S. (2007). Setting standards for CSR: A comparative case study on criteria-formulating organizations. Journal of Business Research. 60(5): 539-548.

Kolk, A. \& van Tulder, R. (2010). International business, corporate social responsibility and sustainable development. International Business Review. 19(2): 119-125.

Kotler, P. \& Lee, N.R. (2008). Social marketing: Influencing behaviors for good (3rd ed.). Thousand Oaks, CA: Sage Publications. 
Kotler, P., Keller, K.L., Brady, M., Goodman, M. \& Hansen, T. (2009). Marketing management (1st European ed.). Harlow: Prentice Hall.

Laidler-Kylander, N. \& Simonin, B., (2009). How international nonprofits build brand equity. International Journal of Nonprofit and Voluntary Sector Marketing. 14(1): 57-69.

Liu, G. \& Ko, W.W. (2011). An Analysis of Cause-Related Marketing Implementation Strategies Through Social Alliance: Partnership Conditions and Strategic Objectives. Journal of Business Ethics. 100(2): 253-281.

MacMillan, K., Money, K., Money, A. \& Downng, S. (2005). Relationship marketing in the not-for-profit sector: an extension and application of the commitment-trust theory. Journal of Business Research. 58(6): 806-818.

Merz, M.A., Peloza, J. \& Chen, Q. (2010). Standardization or localization? Executing corporate philanthropy in international firms. International Journal of Nonprofit and Voluntary Sector Marketing. 15(3): 233-252.

Moosmayer, D.C. \& Fuljahn, A. (2010). Consumer perceptions of cause related marketing campaigns. Journal of Consumer Marketing. 27(6): 543-549.

Sargeant, A. (1999). Marketing management for non-profit organizations. New York, NY: Oxford University Press.

Sarstedt, M. \& Schloderer, M.P. (2010). Developing a measurement approach for reputation of nonprofit organizations. International Journal of Nonprofit and Voluntary Sector Marketing. 15(3): 276299.

Sheikh, S.-ur-R. \& Beise-Zee, R. (2011). Corporate social responsibility or cause-related marketing? The role of cause specificity of CSR. Journal of Consumer Marketing. 28(1): 27-39.

Sorribas, C. (2007). Historic evolution of cause-related marketing programmes. Does a "perfect" CRM programme exist? International Review on Public and Non Profit Marketing. 4(1-2): 149-158.

Sprinkle, G.B. \& Maines, L.A. (2010). The benefits and costs of corporate social responsibility. Business Horizons. 53(5): 445-453.

Stancu, A. (2012). Marketing şi responsabilitate socială. Bucharest: ASE.

Thomas, M.L., Mullen, L.G. \& Fraedrich, J. (2011). Increased word-of-mouth via strategic cause-related marketing. International Journal of Nonprofit and Voluntary Sector Marketing. 16(1): 36-49.

Weerawardena, J., McDonald, R.E. \& Mort, G.S. (2010). Sustainability of nonprofit organizations: An empirical investigation. Journal of World Business. 45(4): 346-356.

Wymer, W. \& Samu, S. (2009). The influence of cause marketing associations on product and cause brand value. International Journal of Nonprofit and Voluntary Sector Marketing. 14(1): 1-20.

Zaharia, R. (2001). Marketing social-politic. Bucharest: Uranus.

Zainon, S., Atan, R., Wah, Y.B. \& Nam, R.Y.T. (2011). Institutional donors' expectation of information from the Non-Profit Organizations (NPOs) reporting: A pilot survey. International NGO Journal. 6(8): $170-18$. 